\title{
Microstructure and Mechanical Properties of Titanium-Equine Bone Biocomposites
}

\author{
Wonki Jeong ${ }^{1}$, Se-Eun Shin ${ }^{1, *(1)}$ and Hyunjoo Choi ${ }^{2}$ \\ 1 Department of Materials Science and Metallurgical Engineering, Sunchon National University, \\ Suncheon 57922, Korea; show4266@naver.com \\ 2 School of Advanced Materials Engineering, Kookmin University, Seoul 02707, Korea; hyunjoo@kookmin.ac.kr \\ * Correspondence: shinsen@scnu.ac.kr
}

Received: 31 March 2020; Accepted: 24 April 2020; Published: 29 April 2020

check for updates

\begin{abstract}
Microstructure and mechanical properties of Ti-6Al-4V/equine bone (EB) composites fabricated by ball milling and spark plasma sintering (SPS) have been investigated. Ti-6Al-4V/EB composites were successfully fabricated by a planetary ball-milling of spherical Ti6Al4V powder and natural EB powder and SPS at $1000{ }^{\circ} \mathrm{C}$ within 15 min under $50 \mathrm{MPa}$. EB was uniformly dispersed in the Ti6Al4V matrix owing to ball-milling, and beta phase transformation temperature of $1000{ }^{\circ} \mathrm{C}$ provided phase stability. The composites containing $0.5 \mathrm{wt} . \%$ EB exhibit Vickers hardness and elastic modulus of $540.6 \mathrm{HV}$ and $130.5 \mathrm{GPa}$, respectively. The microstructures and mechanical properties of the composites were observed using scanning electron micrograph and nanoindentation.
\end{abstract}

Keywords: metal-matrix composites; titanium alloy design; microstructures; mechanical properties; biocomposites; powder metallurgy

\section{Introduction}

Recently, there has been a high demand for implants for bone dysfunction caused by damages, diseases, and fractured bones by aging or accident, so numerous studies related to biomedical implant materials which can function on the damages or fractured bones by aging or accident have been actively conducted [1-3]. According to the distinct required properties for biomedical implants, limited metals or ceramics were selected. The biomedical implants must not react with a tissue of the human body because it causes biological instability due to corrosion or degradation of the implants [4]. Therefore, not only high strength and low stiffness with lightweight but also corrosion resistance in vivo should be satisfied to apply in biomedical applications. For metals, titanium (Ti) and its alloys, stainless steel, and cobalt-chromium alloys have been extensively reported [5,6].

Among the metals, Ti and its alloys are widely used as implant materials owing to excellent biocompatibility with tissues in the human body and high corrosion resistance and mechanical properties [4,7-9]. The Ti-6 aluminum-4 Vanadium (Ti6Al4V) alloy, the most extensively used Ti alloy, has been used successfully for dental and orthopedic implants, due to its high corrosion resistance and osseointegration by a thin oxide layer formed on the surface in a very short time [10]. The oxide layer exists on the surface of thickness in $\sim 2 \mathrm{~nm}$, which prevents elution of the metal ions and provides the corrosion resistance to withstand the intra-vital corrosion environment [11].

Hence, most biomaterials have used hydroxyapatite $\left(\mathrm{Ca}_{10}\left(\mathrm{PO}_{4}\right)_{6}(\mathrm{OH})_{2}\right)$ or calcium pyrophosphate $\left(\mathrm{Ca}_{2} \mathrm{P}_{2} \mathrm{O} \cdot 2 \mathrm{H}_{2} \mathrm{O}\right)$ coated with Ti6Al4V alloys using several coating methods, such as plasma spraying, thermal spraying, and the hot dipping method to increase the osseointegration with the bones [12-15]. In order to give high osteoconductive property to Ti6Al4V alloy, calcium phosphate-based ceramics such as hydroxyapatite are also coated by plasma spraying [16]. 
Especially hydroxyapatite has high biocompatibility, bioactivity, osteoconductive property, and osteoinduction, since a lot of researchers have released results of biomaterials containing hydroxyapatite $[13,15,17-22]$. Meanwhile, biomaterials containing calcium phosphate $\left(\mathrm{Ca}_{3}\left(\mathrm{PO}_{4}\right)_{2}\right)$ from biological wastes such as pig bones, fish bones, and horse bones have been used as raw materials for mass production of natural hydroxyapatite at low cost, according to recent reports [23-25]. Production of the hydroxyapatite from abundant natural sources rather than synthetic sources is much more economical and eco-friendly. In particular, horse bones are free from foot-and-mouth disease and have a positive effect on the extraction of natural calcium phosphate due to the high supply rate and low price due to the increase in the number of slaughter horses.

However, in the case of metal coated with the synthetically-produced hydroxyapatite, detachment of hydroxyapatite from a metallic substrate occurs, which is a fatal disadvantage [26-28]. For instance, biomedical implants coated with calcium phosphates from the natural bones using the spray method may cause necrosis of cells because, during long-term use, the differences in thermal expansion coefficients and mechanical properties between the calcium phosphate and the metallic materials may cause peeling to occur. Therefore, a study on the Ti6Al4V matrix biocomposites containing hydroxyapatite produced by powder metallurgy has suggested that peeling problems can be avoided and presented high strength and low elastic modulus compared to microcrystalline Ti [29].

The aim of the present study is to suggest the fabrication process of the Ti6Al4V/equine bone (EB) composite using powder metallurgy and overcome the peeling of the hydroxyapatite from the Ti6Al4V. Hence, Ti6Al4V/EB composite powders are produced using a low-energy ball-milling and the composite powders rapidly sintered by spark plasma sintering (SPS) have inhibited grain growth and decomposition of hydroxyapatite. The effect of the EB on the microstructure and mechanical properties has been evaluated as a function of EB weight fraction; a quantitative and qualitative analysis of the composites is also done.

\section{Experimental Procedure}

\subsection{Materials and Methods}

Ti6Al4V-EB composites were fabricated by a powder metallurgy route. Commercial powder of pure Ti6Al4V (AP\&C, Quebec, Canada) with a mean particle size of $35 \mu \mathrm{m}$ and a composition of $6.2 \% \mathrm{Al}, 4.1 \% \mathrm{~V}$, and $0.1 \% \mathrm{O}$ in a Ti matrix (weight $\%$ ), and $\mathrm{EB}$ powders (Jeju, Korea) with an average powder size of around $1 \mu \mathrm{m}$ and a composition of $39.4 \% \mathrm{O}, 41.4 \% \mathrm{Ca}, 16.7 \% \mathrm{P}$, and $0.56 \% \mathrm{Mg}$ were used. The Ti6Al4V-EB composite powders of $50 \mathrm{~g}$ were ball-milled and utilized by a planetary mill (Pulverisette 4, Fritsch, Idar-Oberstein, Germany) at a rotational speed of 200 RPM for $12 \mathrm{~h}$, followed by a $40 \mathrm{~min}$ pause after every $20 \mathrm{~min}$ of milling to avoid overheating under air atmosphere. A stainless steel bowl $(500 \mathrm{ml})$ was charged with the Ti6Al4V and EB powders and stainless steel balls without any process control agent. The diameter of the stainless steel balls was $15 \mathrm{~mm}$, and the ball-to-powder weight ratio employed was 5:1. Owing to the shearing mode, EB powders were gradually embedded into the Ti6Al4V powder. The Ti6Al4V and ball-milled Ti6Al4V-EB composite powders were rapidly consolidated using SPS. The composite powders were poured into a $30 \mathrm{~mm}$ graphite die with $10 \mathrm{~g}$, and the heating rate was $100^{\circ} \mathrm{C} / \mathrm{min}$ up to $1000{ }^{\circ} \mathrm{C} / \mathrm{min}$, and maintained for $15 \mathrm{~min}$ at an applied pressure of $50 \mathrm{MPa}$ under a high vacuum atmosphere. After SPS, the pressure was removed, and the sintered specimen was cooled down to room temperature. SPSed Ti6Al4V and Ti6Al4V-EB composites have dimensions of $30 \mathrm{~mm}$ in diameter and $10 \mathrm{~mm}$ in height.

\subsection{Characterizations}

The morphologies of the starting powders, composite powders, and sintered composites were observed using field-emission scanning electron microscopy (FE-SEM, JSM 7001F, JEOL, Tokyo, Japan), and energy dispersive spectroscopy (EDS) revealed the chemical compositions of the powders and the composites. X-ray diffraction (XRD, CN2301, Rigaku, Tokyo, Japan) with a $\mathrm{Cu}-\mathrm{K} \alpha$ radiation source $(\lambda=1.5405 \AA)$ using a step size of $0.02^{\circ}(2 \theta)$, the scanning rate of $1^{\circ} / \mathrm{min}$ from 20 to $100^{\circ}$ to identify the phase constitutions of the composite powders and sintered composites. 
To measure elastic modulus of the composites, SPSed specimens with a $4 \mathrm{~mm}$ cube were ground flat and mechanically polished up to 4000 grit. An ultrasonic technique was used to determine elastic modulus of the composites (5055PR Pulse receiver 5055PR and Oscilloscope 9354CM oscilloscope, LeCoroy Co., NY, USA). A frequency of $5 \mathrm{MHz}$ was applied; the longitudinal velocity and transverse velocities $y$ within the specimens were determined. Nanoindentation tests were performed on the specimens using a commercial nanohardness tester (Nanoindenter XP, MTS, MN, USA) equipped with a Berkovich indenter and measured more than 10 times per each specimen. In each test, the indenter was driven into the sample surface (loading half-cycle) at a rate of $10 \mathrm{~nm} / \mathrm{s}$ and the peak load ranges from 0 to $35 \mathrm{mN}$. The Vickers hardness of the specimens was measured using a micro-Vickers hardness testing machine (Mitutoyo, HM200, Kawasaki, Japan) with an indenter load of 300 N.

\section{Results and Discussion}

\subsection{Microstructures}

Figure 1 shows SEM images of starting powders of Ti6Al4V and EB, and ball-milled powders of Ti6Al4V-EB composite powders as a function of the EB weight fraction (wt.\%); 0.05, 0.5, and 5 wt.\%. The composites containing EB of $0.05,0.5$, and $5 \mathrm{wt}$.\% were expressed as T-0.05EB, T-0.5EB, and $\mathrm{T}-5 \mathrm{~EB}$, respectively. According to the images, the shape of the ball-milled powders was insignificantly changed, but a rough surface iwa shown due to the ball-milling process. During the ball-milling process, physical changes were induced by the impact between the balls and the powders accompanying shear force. Therefore, the size of the powders was slightly increased from 32 to $45 \mu \mathrm{m}$, because certain cold welding could occur between the balls [30]. In the process, nanoscale EB powders were attached to the Ti6Al4V powder surface and then gradually embedded in the Ti6Al4V matrix. Accordingly, EB powders were not observed on the Ti6Al4V powder surface in all composite powders as shown in Figure $1 \mathrm{~d}, \mathrm{f}, \mathrm{h}$. From the elemental analysis using EDS, the key chemical composition was maintained as shown in Figure 1i. The main chemical composition of the hydroxyapatite, such as $\mathrm{Ca}, \mathrm{P}$, and $\mathrm{O}$, increased as the EB contents increased.

Figure 2 presents the SEM images and EDS mapping of SPSed Ti6Al4V and the Ti6Al4V-EB composites with the weight fractions of EB 0.05, 0.5, and 5 wt. $\%$. As shown in the images, $\alpha$-Ti with the hexagonal closed packed (HCP) and $\beta$-Ti with the body-centered cubic (BCC) phases are clearly shown as dark grey and bright grey, respectively, and a volume fraction of $\beta$-Ti phase $\left(f_{\beta}\right)$ is displayed in each of the SEM images. The chemical compositions for each phase from EDS analysis are shown in Table 1. As a reference, defects such as pores and voids were not significantly found in the Ti6Al4V sintered specimen, and the presence and amount of $\beta$-Ti were $12.6 \%$. The sintered composites having a porosity below $1 \%$ and relative density above $99 \%$ on average, excluding Ti6Al4V-5EB composites. Ti6Al4V-5EB composites showed a relative density of $95 \%$, which affects elastic modulus and the hardness results.

Table 1. EDS analysis of the samples with the phase fraction of $\alpha$-Ti and $\beta$-Ti phase from the SEM images of Figure 2.

\begin{tabular}{ccccccccc}
\hline \multirow{2}{*}{ Element } & \multicolumn{2}{c}{ (a) Ti6A14V } & \multicolumn{2}{c}{ (b) T-0.05EB } & \multicolumn{2}{c}{ (c) T-0.5EB } & \multicolumn{2}{c}{ (d) T-5EB } \\
\cline { 2 - 9 } & $\alpha$-Phase & $\beta$-Phase & $\alpha$-Phase & $\beta$-Phase & $\alpha$-Phase & $\beta$-Phase & $\alpha$-Phase & $\beta$-Phase \\
\hline $\mathrm{Al}$ & 5.94 & 5.21 & 6.90 & 5.93 & 6.58 & 5.55 & 6.40 & 6.65 \\
\hline $\mathrm{P}$ & - & - & 0.04 & 0.05 & 0.00 & 0.09 & 0.03 & 0.05 \\
\hline $\mathrm{Ca}$ & - & - & 0.00 & 0.03 & 0.30 & 0.05 & 0.18 & 0.19 \\
\hline $\mathrm{O}$ & 0.18 & 0.15 & 1.29 & 1.51 & 1.97 & 2.54 & 2.3 & 4.2 \\
\hline $\mathrm{Ti}$ & 90.12 & 89.37 & 88.69 & 84.26 & 88.61 & 83.54 & 88.08 & 79.35 \\
\hline $\mathrm{V}$ & 3.76 & 5.28 & 3.08 & 8.22 & 2.54 & 8.23 & 3.01 & 5.37 \\
\hline Totals & 100.00 & 100.00 & 100.0 & 100.0 & 100.0 & 100.0 & 100.0 & 100.0 \\
\hline
\end{tabular}



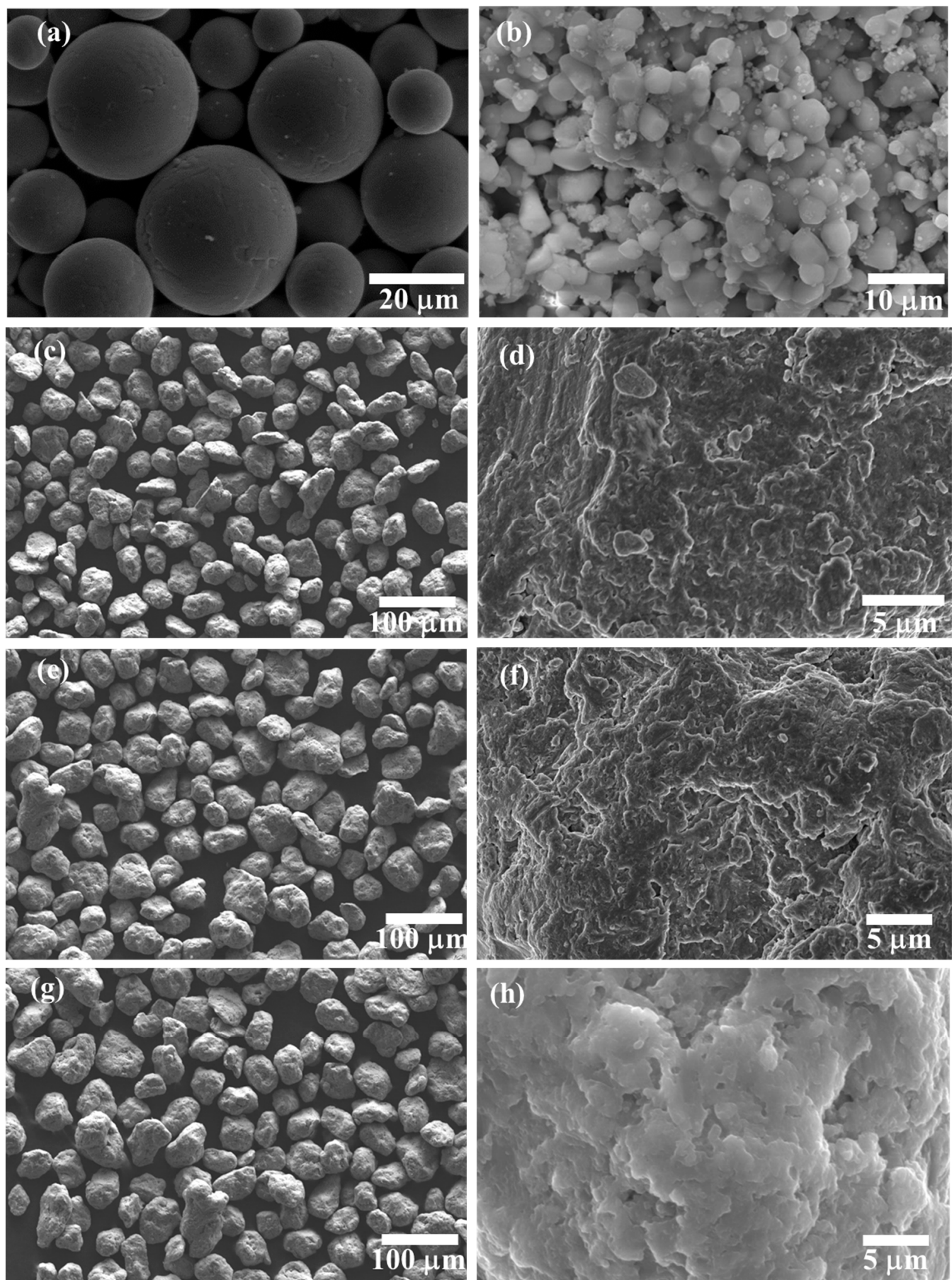

Figure 1. Cont. 


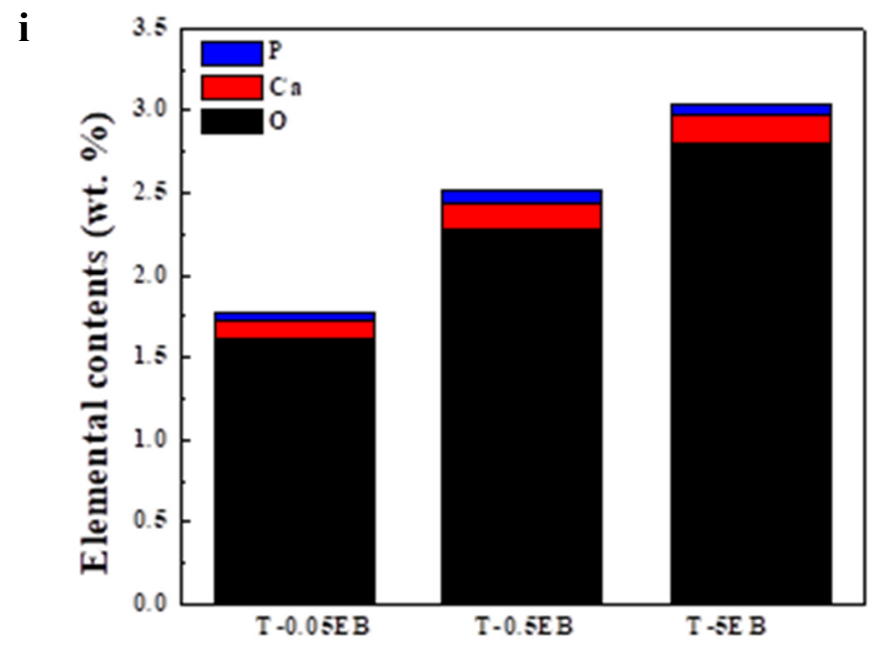

Figure 1. SEM images of starting materials and composite powders as a function of their equine bone (EB) contents; (a) Ti6Al4V; (b) EB; (c,d) T-0.05EB; (e,f) T-0.5EB; and (g,h) T-5EB. (i) Average chemical composition of $\mathrm{Ca}, \mathrm{P}$, and $\mathrm{O}$ in (d), (f), and (h).
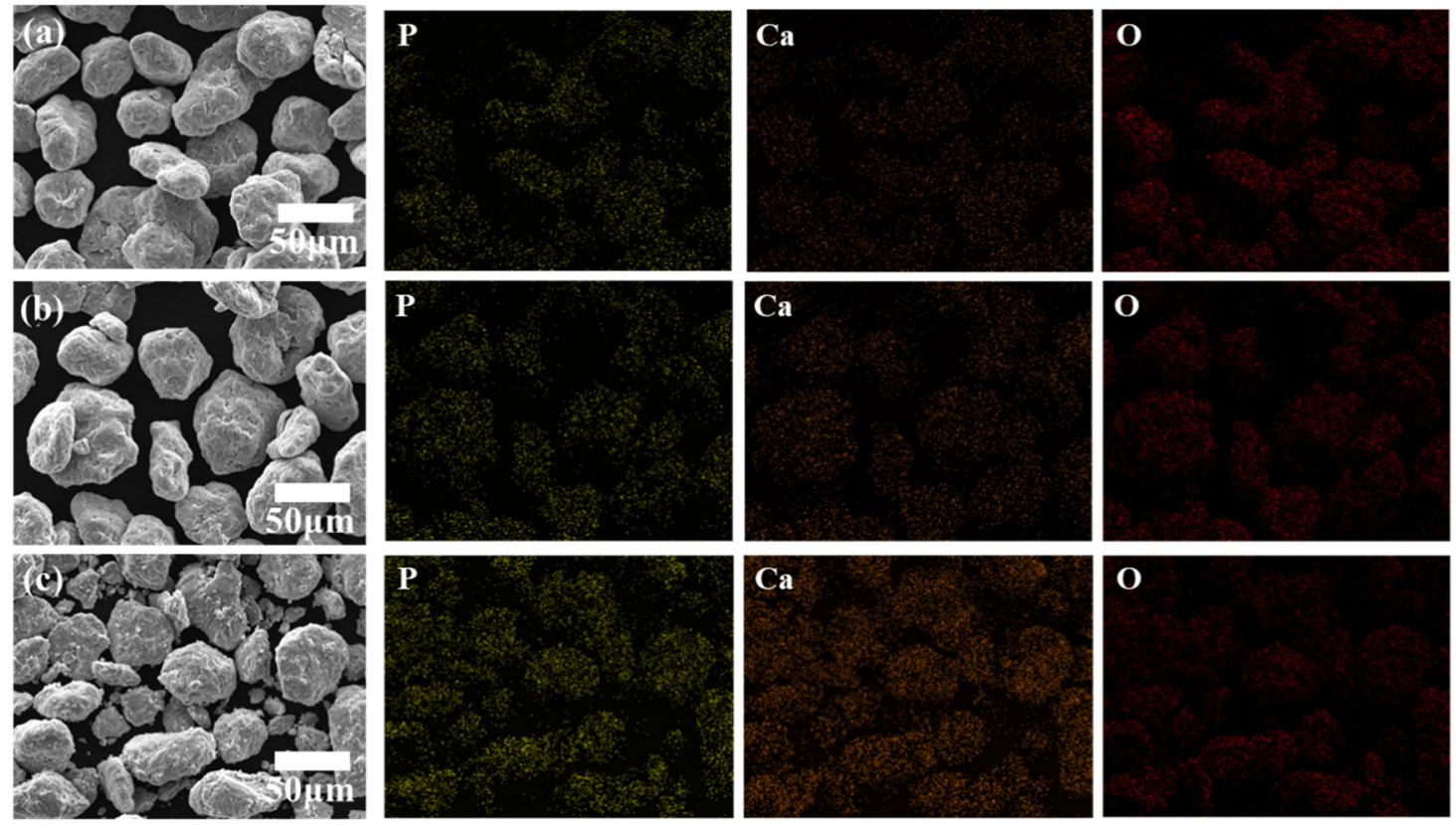

Figure 2. SEM images and EDS analysis of ball-milled Ti6Al4V-EB composites under different weight fraction of the EB; (a) T-0.05Ed; (b) T-0.5EB and (c) T-5EB.

For all cases of Ti6Al4V-EB composites, well-distributed EB and $\alpha+\beta$ morphology were observed. Regarding the distribution of $\mathrm{Al}$ and $\mathrm{V}$, the corresponding concentration ratios for $\alpha$-Ti and $\beta$-Ti were found to be approximately 3:2 and 3:4, respectively (in Figure 3e) [31]. The V concentration in the Ti matrix increased according to the $\beta$-Ti phase transformation. The significance in $f_{\beta}$ is closely related to elastic modulus, which is an important factor as a biomedical material to attain low elastic modulus, because beta phase has a lower elastic modulus than alpha phase [32-34]. The stress shielding effect can occur according to high elastic modulus; therefore, a decrease in elastic modulus is important for biomedical implants [34-37]. The stress shielding effect is defined as the stress transfer between the bone and implant materials which is not homogeneously caused by a difference in elastic modulus. For instance, when the load is applied, the implant with a high elastic modulus mostly absorbs all of the tensile and compressive stresses and bending moments, which were previously applied to the bone; resultantly, osteoporosis or bone loss can occur [36,38,39]. 

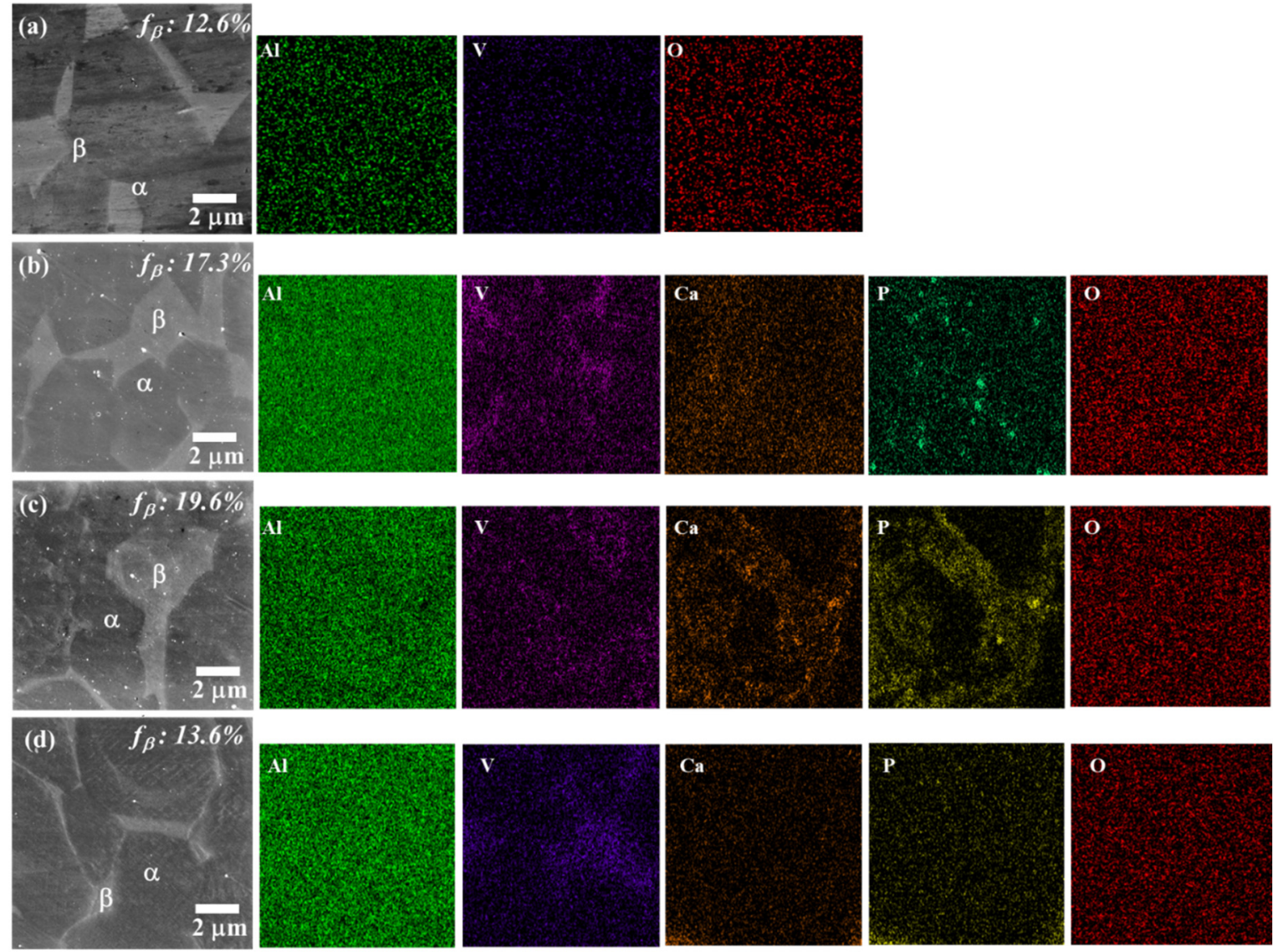

Figure 3. SEM images and EDS analysis of spark plasma sintered (SPSed) Ti6Al4V and Ti6Al4V-EB composites under different weight fraction of the EB; (a) Ti6Al4V; (b) T-0.05EB; (c) T-0.5EB; and (d) T-5EB ( $f$ is a fraction of $\beta$-Ti phase).

Figure 4 shows the XRD analysis of the starting materials and Ti6Al4V-EB composite before and after SPS to identify the elements and the phase distribution. The major peaks are attributed to $\alpha$-Ti (marked by black square), $\beta$-Ti (marked by green square), and hydroxyapatite (marked by a red square). All peaks are in good agreement with each standard spectrum from the JCPDS database; $\alpha$-Ti peaks displayed the (100), (002), (101), (102), and (110) reflection peak around $2 \theta=35.4,38.6,40.5$, 53.4, and 63.7 ${ }^{\circ}$, respectively (JCPDS Card No. 00-044-1294 and 00-009-0098). Although the peaks of hydroxyapatite for the composite powder and SPSed composites were shrouded in major peaks of Ti due to a small amount of EB, peaks from $2 \theta=32^{\circ}$ to $2 \theta=35.2^{\circ}$ for hydroxyapatite (JCPDS Card No. 00-009-0432) were detected, as shown in Figure 3. According to the literature, for sintering up to $1200{ }^{\circ} \mathrm{C}$, hydroxyapatite can prevent decomposition into metastable phases such as tri-calcium phosphate during the sintering [40]. After SPS at $1000^{\circ} \mathrm{C}$, the main peaks were clearly detected for Ti6Al4V-EB composites. Several $\beta$-phases within the Ti6Al4V/EB composites, the (110) reflection peak of which is around $2 \theta=39.7^{\circ}$, are displayed in Figure $4 \mathrm{~b}$. The XRD peak of the $\beta$-Ti phase observed in the T-5EB sample subjected to SPS is shifted to a lower angular position, because more $V$ contents in the matrix, with a lower atomic radius of $0.132 \mathrm{~nm}$, were dissolved in the $\beta$-Ti phase. After SPS, while $2 \theta$ was increased from 40.48 to $40.51^{\circ}$, the peak shifted towards a smaller angle $\theta$ of $0.03^{\circ}$, while when $2 \theta$ was increased from 38.40 to $38.41^{\circ}$, the peak shifted towards a smaller angle $\theta$ of $0.01^{\circ}$. 


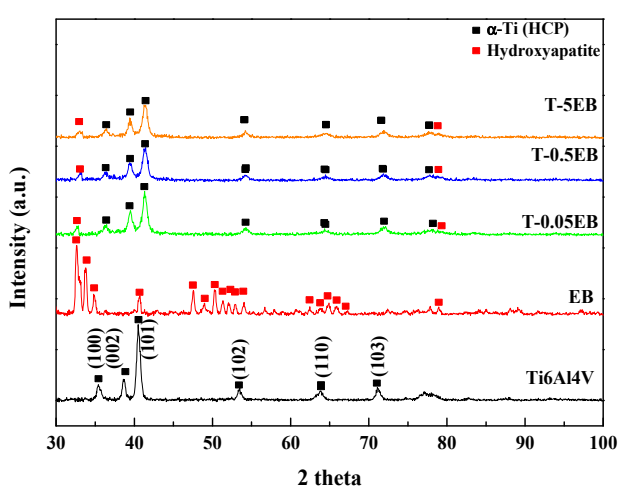

(a)

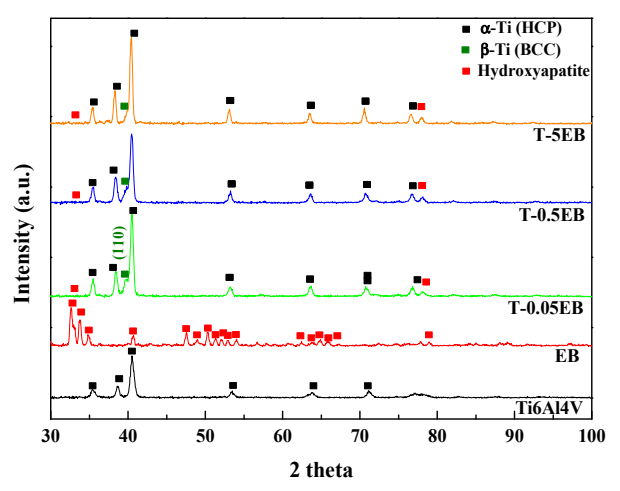

(b)

Figure 4. XRD analysis of the (a) starting powders and the Ti6Al4V-EB composite powders, and (b) SPSed composites.

\subsection{Mechanical Properties}

To estimate the mechanical characteristics for biomedical implants, Vickers hardness and elastic modulus of the Ti6Al4V-EB composites, a function of EB contents, are shown in Figure 5a. For accuracy, the mean average values of the elastic modulus were calculated from ultrasonication method and nanoindentation curves. The increase in Vickers hardness by means of EB contents is because the hardness of hydroxyapatite contained in EB (nanohardness of 5-6 GPa and Vickers hardness of 460-480 HV) is higher than that of the Ti matrix (nanohardness of 2 GPa and Vickers hardness of 350-400 HV) [41-44]. In addition, nanoscale hydroxyapatite was uniformly dispersed in the Ti6Al4V matrix, thereby strengthening particle effects on the hardness increment. The hardness increases as the amount of EB added increases; this increment is based on the previous studies which showed that the hardness can be increased by adding a ceramic material such as EB to the Ti matrix. When hydroxyapatite particles from EB are added to the Ti matrix, the hydroxyapatite particles are allowed to act as a barrier to dislocations $[29,45]$. Therefore, the values of Vickers hardness for Ti6Al4V-EB composites have been shown to range from 503.3 to $690.1 \mathrm{HV}$, which is 1.4-2 times higher than that of pure Ti6Al4V [44]. However, the values of elastic modulus have displayed a different trend compared to those of Vickers hardness. In general, elastic modulus values for Ti6Al4V-EB composites, which range from 133.2 to $139.7 \mathrm{GPa}$, are slightly higher than those of Ti6Al4V (114 GPa); however, it depends on the fraction of $\beta$-Ti among the composites (in Figure 2). Therefore, the composite containing the highest $f_{\beta}$ of $19.6 \%$ showed the lowest elastic modulus value of $130.5 \mathrm{GPa}$, rather than the composite containing a $f_{\beta}$ of $13.6 \%$ with the $139.7 \mathrm{GPa}$. In addition, oxygen from EB is a typical stabilizing element for $\alpha$-Ti-that is, as the amount of EB increased, the fraction of $\alpha$-Ti having a relatively high elastic modulus was increased due to the stabilizing element. Thus, the elastic moduli of the SPSed composites also increased. Further, the elastic moduli of the SPSed samples were affected by the density; the Ti6Al4V-0.5EB composites showed the lowest elastic moduli due to having a relatively low density of $95 \%$. Consequently, this result showed that the proper selection of process conditions for the fabrication of Ti6Al4V matrix composites could have high strength and suitable elastic moduli for use as biomedical implants. For instance, when the composites are sintered above $1200{ }^{\circ} \mathrm{C}$, hydroxyapatite can phase transform to a meta-stable phase such as tricalcium phosphate, which may lead to biodegradation in the human body [40]. 


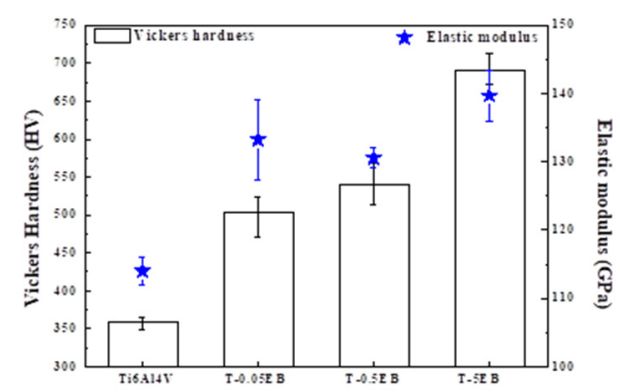

(a)

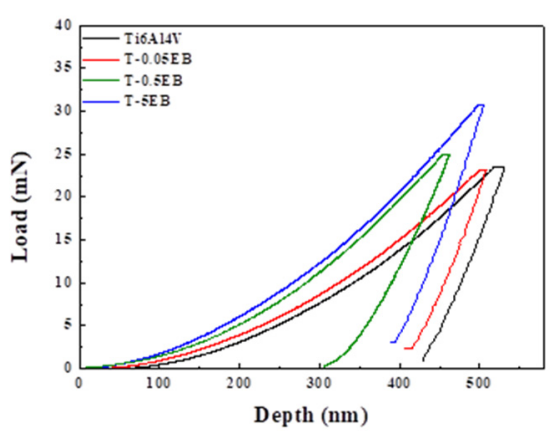

(b)

Figure 5. Mechanical properties of the Ti6Al4V and Ti6Al4V/HB composites. (a) Vickers hardness and elastic modulus, and (b) stress-strain curves from nanoindentation.

\section{Conclusions}

In this study, Ti6Al4V powder, which was used as a metal matrix of biocomposites and EB powder with excellent bioactivity, was successfully manufactured using powder metallurgy and SPS. The Ti6Al4V-EB composite powders as a function of EB mass fraction $(0.05,0.5$, and $5 \mathrm{wt} . \%)$ were ball-milled for $12 \mathrm{~h}$, and the bulk composites were consolidated using SPS at $1000^{\circ} \mathrm{C}$. The microstructures with phase analysis and mechanical properties were analyzed using the sintered Ti6Al4V-EB composites.

(1) The existence of hydroxyapatite, the major component of equine bones, in both Ti6Al4V-EB composite powder and sintered Ti6Al4V-EB composites, was confirmed by SEM-EDS and XRD analysis.

(2) The hardness of the Ti6Al4V-EB composites increased as the EB contents increased owing to uniformly distribution of EB in the Ti6Al4V matrix. The composites SPSed at $1000{ }^{\circ} \mathrm{C}$, which is the beta-phase transformation temperature, provided well-fabricated specimens and showed reasonable mechanical properties.

(3) The composites containing 0.5 wt.\% EB exhibited Vickers hardness and elastic modulus of 540.6 HV and 130.5 GPa, which are high strength and reasonable stiffness values for biomedical implants. Slightly high elastic modulus values of the composites can cause stress shielding problems compared to Ti6Al4V (110 GPa).

(4) $\mathrm{Ca}, \mathrm{P}$, and $\mathrm{O}$ constituting the hydroxyapatite were detected on the surface of all Ti6Al4V-EB composites, which is no change of surface components before and after sintering due to discharge plasma sintering. Therefore, this study can suggest that the Ti6Al4V-EB composites have high bioactivity by increasing the bonding strength between implant and bone.

Author Contributions: Formal analysis, W.J.; Methodology, W.J.; Resources, H.C.; Supervision, S.-E.S.; alidation, H.C.; Writing-original draft, W.J.; Writing-review \& editing, S.-E.S. All authors have read and agreed to the published version of the manuscript.

Funding: This research was funded by Korean Ministry of Trade, Industry and Energy (MOTIE), grant number: P0002019.

Acknowledgments: This research was funded and conducted under "the Competency Development Program for Industry Specialists" of the Korean Ministry of Trade, Industry and Energy (MOTIE), operated by Korea Institute for Advancement of Technology (KIAT)(No. P0002019, HRD Program for High Value-Added Metallic Material Expert).

Conflicts of Interest: The authors declare no conflict of interest. 


\section{References}

1. Wally, Z.J.; Van Grunsven, W.; Claeyssens, F.; Goodall, R.; Reilly, G.C. Porous titanium for dental implant applications. Metals 2015, 5, 1902-1920. [CrossRef]

2. Yemisci, I.; Mutlu, O.; Gulsoy, N.; Kunal, K.; Atre, S.; Gulsoy, H.O. Experimentation and analysis of powder injection molded Ti10Nb10Zr alloy: A promising candidate for electrochemical and biomedical application. J. Mater. Res. Technol. 2019, 8, 5233-5245. [CrossRef]

3. Slokar, L.; Štrkalj, A.; Glavaš, Z. Synthesis of Ti-Zr alloy by powder metallurgy. Eng. Rev. 2019, 39, 115-123. [CrossRef]

4. Wu, S.; Liu, X.; Yeung, K.W.; Guo, H.; Li, P.; Hu, T.; Chung, C.Y.; Chu, P.K. Surface nano-architectures and their effects on the mechanical properties and corrosion behavior of Ti-based orthopedic implants. Surf. Coat. Technol. 2013, 233, 13-26. [CrossRef]

5. Hsieh, M.-F.; Perng, L.-H.; Chin, T.-S. Hydroxyapatite coating on Ti6Al4V alloy using a sol-gel derived precursor. Mater. Chem. Phys. 2002, 74, 245-250. [CrossRef]

6. Best, S.M.; Porter, A.E.; Thian, E.S.; Huang, J. Bioceramics: Past, present and for the future. J. Eur. Ceram. Soc. 2008, 28, 1319-1327. [CrossRef]

7. Sousa, S.R.; Barbosa, M.A. Effect of hydroxyapatite thickness on metal ion release from Ti6Al4V substrates. Biomaterials 1996, 17, 397-404. [CrossRef]

8. Gu, Y.W.; Khor, K.A.; Cheang, P. In vitro studies of plasma-sprayed hydroxyapatite/Ti-6Al-4V composite coatings in simulated body fluid (SBF). Biomaterials 2003, 24, 1603-1611. [CrossRef]

9. Linez-Bataillon, P.; Monchau, F.; Bigerelle, M.; Hildebrand, H.F. In vitro MC3T3 osteoblast adhesion with respect to surface roughness of Ti6Al4V substrates. Biomol. Eng. 2002, 19, 133-141. [CrossRef]

10. Meachim, G.; Williams, D. Changes in nonosseous tissue adjacent to titanium implants. J. Biomed. Mater. Res. 1973, 7, 555-572. [CrossRef]

11. Fojt, J. Ti-6Al-4V alloy surface modification for medical applications. Appl. Surf. Sci. 2012, 262, $163-167$. [CrossRef]

12. Evans, S.L.; Gregson, P.J. The effect of a plasma-sprayed hydroxyapatite coating on the fatigue properties of Ti-6Al-4V. Mater. Lett. 1993, 16, 270-274. [CrossRef]

13. Kweh, S.W.K.; Khor, K.A.; Cheang, P. Plasma-sprayed hydroxyapatite (HA) coatings with flame-spheroidized feedstock: Microstructure and mechanical properties. Biomaterials 2000, 21, 1223-1234. [CrossRef]

14. Wen, C. Surface coating and modification of metallic biomaterials; Woodhead Publishing: Cambridge, UK, 2015.

15. Sidane, D.; Chicot, D.; Yala, S.; Ziani, S.; Khireddine, H.; Iost, A.; Decoopman, X. Study of the mechanical behavior and corrosion resistance of hydroxyapatite sol-gel thin coatings on $316 \mathrm{~L}$ stainless steel pre-coated with titania film. Thin Solid Films 2015, 593, 71-80. [CrossRef]

16. Pilliar, R.; Deporter, D.; Watson, P.; Pharoah, M.; Chipman, M.; Valiquette, N.; Carter, S.; De Groot, K. The effect of partial coating with hydroxyapatite on bone remodeling in relation to porous-coated titanium-alloy dental implants in the dog. J. Dent. Res. 1991, 70, 1338-1345. [CrossRef]

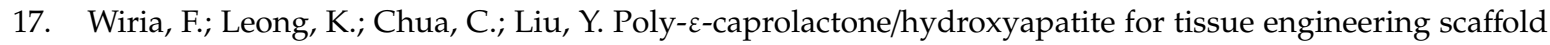
fabrication via selective laser sintering. Acta. Biomater. 2007, 3, 1-12. [CrossRef]

18. Guizzardi, S.; Montanari, C.; Migliaccio, S.; Strocchi, R.; Solmi, R.; Martini, D.; Ruggeri, A. Qualitative assessment of natural apatite in vitro and in vivo. J. Biomed. Mater. Res. 2000, 53, 227-234. [CrossRef]

19. Arifin, A.; Sulong, A.B.; Muhamad, N.; Syarif, J.; Ramli, M.I. Material processing of hydroxyapatite and titanium alloy (HA/Ti) composite as implant materials using powder metallurgy: A review. Mater. Des. 2014, 55, 165-175. [CrossRef]

20. Knabe, C.; Berger, G.; Gildenhaar, R.; Klar, F.; Zreiqat, H. The modulation of osteogenesis in vitro by calcium titanium phosphate coatings. Biomaterials 2004, 25, 4911-4919. [CrossRef]

21. Li, F.; Jiang, X.; Shao, Z.; Zhu, D.; Luo, Z. Research Progress Regarding Interfacial Characteristics and the Strengthening Mechanisms of Titanium Alloy/Hydroxyapatite Composites. Materials 2018, 11, 1391. [CrossRef]

22. Hameed, P.; Gopal, V.; Bjorklund, S.; Ganvir, A.; Sen, D.; Markocsan, N.; Manivasagam, G. Axial Suspension Plasma Spraying: An ultimate technique to tailor Ti6Al4V surface with HAp for orthopaedic applications. Colloids Surf. B 2019, 173, 806-815. [CrossRef] [PubMed] 
23. Matsumoto, T.; Kawakami, M.; Kuribayashi, K.; Takenaka, T.; Minamide, A.; Tamaki, T. Effects of sintered bovine bone on cell proliferation, collagen synthesis, and osteoblastic expression in MC3T3-E1 osteoblast-like cells. J. Orthop. Res. Off. Publ. Orthop. Res. Soc. 1999, 17, 586-592. [CrossRef] [PubMed]

24. Ooi, C.Y.; Hamdi, M.; Ramesh, S. Properties of hydroxyapatite produced by annealing of bovine bone. Ceram. Int. 2007, 33, 1171-1177. [CrossRef]

25. Jang, K.-J.; Cho, W.J.; Seonwoo, H.; Kim, J.; Lim, K.T.; Chung, P.-H.; Chung, J.H. Development and Characterization of Horse Bone-derived Natural Calcium Phosphate Powders. J. Biosyst. Eng. 2014, 39, 122-133. [CrossRef]

26. Yan, W.-Q.; Nakamura, T.; Kawanabe, K.; Nishigochi, S.; Oka, M.; Kokubo, T. Apatite layer-coated titanium for use as bone bonding implants. Biomaterials 1997, 18, 1185-1190. [CrossRef]

27. Belcarz, A.; Bieniaś, J.; Surowska, B.; Ginalska, G. Studies of bacterial adhesion on TiN, SiO2-TiO2 and hydroxyapatite thin layers deposited on titanium and Ti6Al4V alloy for medical applications. Thin Solid Films 2010, 519, 797-803. [CrossRef]

28. Uezono, M.; Takakuda, K.; Kikuchi, M.; Suzuki, S.; Moriyama, K. Hydroxyapatite/collagen nanocompositecoated titanium rod for achieving rapid osseointegration onto bone surface. J. Biomed. Mater. Res. B 2013, 101B, 1031-1038. [CrossRef]

29. Niespodziana, K.; Jurczyk, K.; Jakubowicz, J.; Jurczyk, M. Fabrication and properties of titaniumhydroxyapatite nanocomposites. Mater. Chem. Phys. 2010, 123, 160-165. [CrossRef]

30. Benjamin, J.; Volin, T. The mechanism of mechanical alloying. Metall. Trans. 1974, 5, 1929-1934. [CrossRef]

31. Semiatin, S.; Knisley, S.; Fagin, P.; Barker, D.; Zhang, F. Microstructure evolution during alpha-beta heat treatment of Ti-6Al-4V. Metall. Mater. Trans. A 2003, 34, 2377-2386. [CrossRef]

32. Prendergast, P.; Taylor, D. Stress analysis of the proximo-medial femur after total hip replacement. J. Biomed. Eng. 1990, 12, 379-382. [CrossRef]

33. Sumner, D.R.; Galante, J.O. Determinants of stress shielding. Clin. Orthop. Relat. Res. 1991, 274, $202-212$. [CrossRef]

34. Van Rietbergen, B.; Huiskes, R.; Weinans, H.; Sumner, D.; Turner, T.; Galante, J. The mechanism of bone remodeling and resorption around press-fitted THA stems. J. Biomech. 1993, 26, 369-382. [CrossRef]

35. Schreurs, B.W.; Huiskes, R.; Buma, P.; Slooff, T.J.J.H. Biomechanical and histological evaluation of a hydroxyapatite-coated titanium femoral stem fixed with an intramedullary morsellized bone grafting technique: An animal experiment on goats. Biomaterials 1996, 17, 1177-1186. [CrossRef]

36. Niinomi, M.; Nakai, M. Titanium-based biomaterials for preventing stress shielding between implant devices and bone. Inter. J. Biomater. 2011, 2011. [CrossRef] [PubMed]

37. Ning, C.; Zhou, Y. On the microstructure of biocomposites sintered from Ti, HA and bioactive glass. Biomaterials 2004, 25, 3379-3387. [CrossRef] [PubMed]

38. Dujovne, A.; Bobyn, J.; Krygier, J.; Miller, J.; Brooks, C. Mechanical compatibility of noncemented hip prostheses with the human femur. J. Arthroplasty 1993, 8, 7-22. [CrossRef]

39. Niinomi, M. Mechanical properties of biomedical titanium alloys. Mater. Sci. Eng. A 1998, 243, 231-236. [CrossRef]

40. Ruys, A.; Wei, M.; Sorrell, C.; Dickson, M.; Brandwood, A.; Milthorpe, B. Sintering effects on the strength of hydroxyapatite. Biomaterials 1995, 16, 409-415. [CrossRef]

41. Zhao, X.; Liu, Q.; Yang, J.; Zhang, W.; Wang, Y. Sintering Behavior and Mechanical Properties of Mullite Fibers/Hydroxyapatite Ceramic. Materials 2018, 11, 1859. [CrossRef]

42. Kumari, R.; Scharnweber, T.; Pfleging, W.; Besser, H.; Majumdar, J.D. Laser surface textured titanium alloy (Ti-6Al-4V)-Part II-Studies on bio-compatibility. Appl. Surf. Sci. 2015, 357, 750-758. [CrossRef]

43. Thijs, L.; Verhaeghe, F.; Craeghs, T.; Humbeeck, J.V.; Kruth, J.-P. A study of the microstructural evolution during selective laser melting of Ti-6Al-4V. Acta. Mater. 2010, 58, 3303-3312. [CrossRef]

44. Woo, K.D.; Kim, S.H.; Kim, J.Y.; Park, S.H. Fabrication and Biomaterial Characteristics of HA added Ti-Nb-HA Composite Fabricated by Rapid Sintering. Korean J. Met. Mater. 2012, 50, 86-91. [CrossRef]

45. Bovand, D.; Yousefpour, M.; Rasouli, S.; Bagherifard, S.; Bovand, N.; Tamayol, A. Characterization of Ti-HA composite fabricated by mechanical alloying. Mater. Des. (1980-2015) 2015, 65, 447-453. [CrossRef]

(C) 2020 by the authors. Licensee MDPI, Basel, Switzerland. This article is an open access article distributed under the terms and conditions of the Creative Commons Attribution (CC BY) license (http://creativecommons.org/licenses/by/4.0/). 